\title{
Collisional Relaxation of Metastable Electronic States of $\mathrm{Fe}^{+}$
}

\author{
D. H. Russell, T. Solouki, and J. V. B. Oriedo \\ Laboratory for Biological Mass Spectrometry, Department of Chemistry, Texas A \& M University, \\ College Station, Texas USA
}

\begin{abstract}
The overall rate constants for collisional relaxation of metastable excited states $\mathrm{Ff}^{+}$by $\mathrm{He}$, Ar, $\mathrm{Kr}, \mathrm{H}_{2},{ }^{2} \mathrm{H}_{2}, \mathrm{CO}, \mathrm{N}_{2}, \mathrm{NO}, \mathrm{CH}_{4}$, and $\mathrm{CH}_{3} \mathrm{OH}$ have been studied by using chargeexchange ion-molecule reaction chemistry. The rate constants vary according to the nature of the quenching reagent as well as the energy level and electron configuration of the $\mathrm{Fe}^{+}$ions. In general, $\mathrm{NO}, \mathrm{CH}_{4}$, and $\mathrm{CH}_{3} \mathrm{OH}$ are the most efficient quenching reagents with rate constants that approach the Langevin collision rate, whereas the reaction rates for the rare gas atoms are slow and vary depending upon the specific electron configuration of the $\mathrm{Fe}^{+}$ ion. The mechanism of collisional relaxation is discussed with emphasis on a curve-crossing mechanism for the rare gas atoms. An electron-transfer mechanism is described for the relaxation of high lying $\left(\mathrm{Fe}^{+}\right)^{*}$. (J Am Soc Mass Spectrom 1995, 6, 543-553)
\end{abstract}

$O$ tudies of gas-phase ion-molecule chemistry that involve atomic transition metal ions have increased steadily over the last decade (see, for example, [1]). Much of the previous work has dealt with fundamental studies of gas-phase ions [2], but more recently there has been growing interest in applications of metal ion chemistry as selective ionization reagents and structural probes of complex molecules [3]. Much of the present work focuses on how the reactivity of $\mathrm{M}^{+}$changes if different excited states are formed by the ionizing process.

A long range objective of our research is to use $\mathrm{M}^{+}$ ions to ionize biomolecules to form ionic complexes. If the ionic complex is formed with excess internal energy, possibly due to an excited state of $\mathrm{M}^{+}$, dissociation may provide useful structural information about the reacting neutral. Alternatively, the ionic complex could be activated by collisions [4] or photon absorption [5] to yield structural information. At this juncture we want to be able to bracket the energy of the reacting $\mathrm{M}^{+}$ions so that we can determine if ground state and excited state ions react differently and to identify which product ions are formed by which ions. For example, a number of studies compare the reactivity of $\mathrm{M}^{+}$formed by different ionizing methods [e.g., surface ionization (SI) versus electron ionization and fragmentation of larger species ionized by electron ionization (EI)] [2d, $2 \mathrm{~g}, 2 \mathrm{~h}]$. The SI method produces predominately ground state ions, denoted $\left(\mathrm{M}^{+}\right)^{\circ}$, and the EI method produces a significant amount of excited state ions, denoted $\left(\mathrm{M}^{+}\right)^{*}$. Other studies have

Address reprint requests to Dr. David H. Russell, Department of Chemistry, Texas A \& M University, Laboratory for Biological Mass Spectrometry, College Station, TX 77843. sought to produce $\left(\mathrm{M}^{+}\right)^{\circ}$ ions by initial formation of reactant $\mathrm{M}^{+}$by electron ionization of volatile metalcontaining compounds (e.g., metal carbonyl) or laser vaporization, and then allowing $\mathrm{M}^{+}$to undergo collisions with a bath gas such as Ar to deplete the electronically excited ions $[2 \mathrm{~d}, 6]$.

Despite recent progress in state-selected chemistry involving $\mathrm{M}^{+}$, few detailed collisional relaxation studies of $\left(\mathrm{M}^{+}\right)^{*}$ have been reported. Strobel and Ridge [2i] studied the reactions of electronically excited $\left(\mathrm{Mn}^{+}\right)^{*}$ ions with $\mathrm{CH}_{4}$ and found that ionic product ions are not formed because the competitive energy transfer process (collisional relaxation) is more efficient. In the same study Strobel and Ridge estimated that the rate constant for the collisional relaxation of $\left(\mathrm{Mn}^{+}\right)^{*}$ by $\mathrm{CH}_{4}$ to form $\left(\mathrm{Mn}^{+}\right)^{\circ}$ is $(1.88 \pm 0.35) \times 10^{-9} \mathrm{~cm}^{3}$ molecule $\mathrm{s}^{-1}$. In an earlier study Ridge and co-workers [2h] observed that electronically excited $\left(\mathrm{Cr}^{+}\right)^{*}$ ions react with $\mathrm{CH}_{4}$ via two pathways, namely, collisional relaxation and formation of ionic products, and the primary process is collisional relaxation to form ground state $\mathrm{Cr}^{+}$ions. They invoked a chemical relaxation mechanism to explain the spin-forbidden collisional relaxation of $\left(\mathrm{Cr}^{+}\right)^{*}$ and $\left(\mathrm{Mn}^{+}\right)^{*}$ by $\mathrm{CH}_{4}$ [2h, 2i]. Armentrout and co-workers [7] also examined collisional relaxation of electronically excited $\mathrm{Fe}^{+}$ions by $\mathrm{He}$ and $\mathrm{Ar}$ in an ion beam experiment. Their results show that collisional relaxation (by $\mathrm{He}$ or $\mathrm{Ar}$ ) of $\left(\mathrm{Fe}^{+}\right)^{*}$ ions to form ground state $\left(\mathrm{Fe}^{+}\right)^{\circ}$ ions is inefficient. For example, a small fraction of the $\left(\mathrm{Fe}^{+}\right)^{*}$ ions are not completely quenched by approximately $10^{5}$ collisions with He. Armentrout and co-workers postulated a curve-crossing mechanism to explain collisional relaxation of $\left(\mathrm{Fe}^{+}\right)^{*}$ ions by rare gas atoms [4]. Kemper and Bowers developed an ion mobility experiment, re- 
ferred to as electronic state chromatography (ESC), that can be used to separate ions of the same metal on the basis of electron configuration. $\left(\mathrm{M}^{+}\right)^{*}$ with different electron configurations exhibit different spatial and temporal distributions as they diffuse through a buffer gas. Collisional relaxation is observed as a "filling in" between the $\left(\mathrm{M}^{+}\right)^{*}$ arrival time distribution (ATD) peak and the $\left(\mathrm{M}^{+}\right)^{\circ}$ peak in cases where the peaks are well resolved. Collisional relaxation in the ESC experiment occurs only in cases where $\left(\mathrm{M}^{+}\right)^{*}$. ion has a $3 d^{n}$ electronic configuration and a $4 s^{1} 3 d^{n-1}\left(\mathrm{M}^{+}\right)^{\circ}$ electronic configuration. $\left(\mathrm{Mn}^{+}\right)^{*}$ and $\left(\mathrm{Fe}^{+}\right)^{*}$ are the only ions reported to undergo collisional relaxation with $\mathrm{He}$ at low drift fields. However, $\left(\mathrm{V}^{+}\right)^{*}$ and $\left(\mathrm{Co}^{+}\right)^{*}$ show substantial increases in deactivation at high drift fields, whereas other $\left(\mathrm{M}^{+}\right)^{*}$ ions do not collisionally relax to form $\left(\mathrm{M}^{+}\right)^{\circ}$ at high drift fields. Kemper and Bowers also invoked a curve-crossing mechanism proposed by Armentrout and co-workers to explain their observations.

We recently reported the use of dissociative and nondissociative charge-exchange ion-molecule reaction chemistry to measure the relative abundance of metastable electronic states of $\left(\mathrm{M}^{+}\right)^{*}[5]$. We now use this method coupled with a differentially pumped two-section cell Fourier-transform ion cyclotron resonance mass spectrometer (FT-ICR/MS) to probe the collisional relaxation of metastable electronic states of $\left(\mathrm{M}^{+}\right)^{*}$. Results from these studies show that the collisional relaxation efficiencies depend not only on the individual electronic states of the $\left(\mathrm{M}^{+}\right)^{*}$ ion, but also on the nature of the collisional relaxation reagent. For instance, in a previous paper [2a] we proposed that electronically excited $\left(\mathrm{Fe}^{+}\right)^{*}$ ions undergo collisional relaxation with NO to form a $4 s^{2} d^{5}\left(\mathrm{Fe}^{+}\right)^{*}$ ion and ${ }^{6} D$ $\left(\mathrm{Fe}^{+}\right)^{\circ}$ ion, and the $4 s^{2} 3 d^{5}\left(\mathrm{Fe}^{+}\right)^{*}$ ion is unreactive (does not collisionally relax to form ionic products) with NO. In this paper, we show that the rate constants for the collisional relaxation process depend upon the specific $\left(\mathrm{Fe}^{+}\right)^{*}$ ion and the nature of the quenching reagent. The overall bimolecular collisional relaxation rates to form $\left(\mathrm{Fe}^{+}\right)^{\circ}$ are also determined on the basis of clustering ion-molecule reaction energy [8]. The collisional relaxation rate constant for $\left(\mathrm{Fe}^{+}\right)^{*}$ ions of different energies and with different reagents are compared.

\section{Experimental}

The instrument used for these studies has been described in detail elsewhere [9]. Briefly, the instrument consists of a custom-built, differentially pumped two-section ion cyclotron resonance (ICR) cell and vacuum system, an Extrel (Madison, WI) FTMS 2001 computer-electronics system, and a 3-T (15-cm bore) superconducting Oxford magnet. The two-section cell consists of two $3.8 \times 3.8 \times 3.8-\mathrm{cm}$ cells that share a common trap plate that serves as a conductance limit. The conductance limit has a $1-\mathrm{mm}$ radius aperture in the center that allows ions to be transferred between the two differentially pumped cell regions [10].

Samples were introduced into the cell by variable leak valves [Varian (Walnut Creek, CA) model 9515100] and the static pressure of the gas was measured by a series 270 Granville Phillips (Boulder, $\mathrm{CO}$ ) ionization gauge controller. The reactant $\mathrm{Fe}^{+}$ions were produced by $70-\mathrm{eV}$ electron impact (EI) ionization of $\mathrm{Fe}(\mathrm{CO})_{5}$. The electron beam energy reading was corrected following calibration to the ionization energy of argon [15.76 eV for $\mathrm{Ar}^{+}\left({ }^{2} P_{3 / 2}\right)$ ] [11]. The electron emitter emission current was regulated by maintaining a constant current of $2 \pm 0.2 \mu \mathrm{A}$ between the filament and a collector positioned approximately $1 \mathrm{~cm}$ behind the filament. The electron beam current that traverses the ion cell under these conditions is approximately $100 \mathrm{nA}$. It is important to maintain this level of electron beam current to prevent overfilling the trap with ions, which would result in space-charge effects. The electron beam was pulsed on for a duration of $5 \mathrm{~ms}$ and ion cell trapping voltage was varied over the range 1 to $6 \mathrm{~V}(25-150 \mathrm{~V} / \mathrm{m})$.

The experiments described in this study were performed by using the two-section ion cell mode. $\mathrm{Fe}(\mathrm{CO})_{5}$ was introduced in region 1 and the quenching reagents were introduced in region 2 . Both regions 1 and 2 were maintained at a static pressure of $2 \times 10^{-7}$ torr after the introduction of $\mathrm{Fe}(\mathrm{CO})_{5}$ and the various quenching reagents in the respective regions. The experimental pulse sequence for two-section ion cell experiments and specific details of the two-section ion cell ion transfer experiments can be found elsewhere [12, 13]. $\mathrm{Fe}(\mathrm{CO})_{5}$ was ionized in region 1 of the two-section cell, and the reactant $\mathrm{Fe}^{+}$was then isolated by using ionejection techniques [14]. Mass selection of $\mathrm{Fe}^{+}$by ion ejection was accomplished by sweeping the rf oscillator over two ranges of frequencies ("chirp excitation" method). The first ejection sweep was over a frequency range that corresponds to $m / z 18$ to 36 , and the second ejection sweep covered the frequencies that corresponds to $m / z 76$ to 300 . The rf oscillator was swept over these two frequency ranges to eject all unwanted ions as well as to minimize translational excitation of $\mathrm{Fe}^{+}$ions caused by both "off-resonance" excitation and tailing of the chirp excitation [15]. Following the isolation step, $\mathrm{Fe}^{+}$was transferred to region 2 of the two-section ion cell and allowed to undergo collisions with various reagents $\left(\mathrm{He}, \mathrm{Ar}, \mathrm{Kr}, \mathrm{H}_{2},{ }^{2} \mathrm{H}_{2}, \mathrm{CO}, \mathrm{N}_{2}\right.$, $\mathrm{NO}, \mathrm{CH}_{4}$, and $\left.\mathrm{CH}_{3} \mathrm{OH}\right)$. The collisional relaxation time between $\mathrm{Fe}^{+}$and the quenching reagents was varied between 0 and $2 \mathrm{~s}$. $\mathrm{Fe}^{+}$ions were then repartitioned back to the reaction chamber (region 1) and allowed to react with the neutral $\mathrm{Fe}(\mathrm{CO})_{5}$ for $100 \mathrm{~ms}$.

Ions previously trapped in both regions of the twosection ion cell were removed by applying a "quench" pulse before new ions were formed. Following isolation of the reactant $\mathrm{Fe}^{+}$as described above, ions trapped in region 2 of the two-section ion cell during the ion formation step were removed by another 
"quench" pulse before the reactant $\mathrm{Fe}^{+}$was partitioned to region 2. Following collisional relaxation of $\mathrm{Fe}^{+}$, the reaction chamber (region 1) was again "quenched," that is, the previously trapped $\mathrm{Fe}^{+}$ions that did not transfer to region 2 during the initial ion transfer event were removed from region 1 of the ion cell.

In these types of studies, it is important to ensure that the reactant $\mathrm{M}^{+}$is cleanly isolated to unequivocally assign the observed chemistry. For example, 70-eV electron impact of $\mathrm{Fe}(\mathrm{CO})_{5}$ can produce doubly charged ions [16]. One such possibility that was a concern in these experiments is the $\mathrm{Fe}(\mathrm{CO})_{2}^{2+}$ doubly charged ion with the same nominal mass-to-charge ratio value as $\mathrm{Fe}^{+}$. We previously examined this issue by high resolution mass measurement and showed that the signal at $m / z 56$ is $>96 \% \mathrm{Fe}^{+}$and the abundance of ions such as $\mathrm{Fe}(\mathrm{CO})_{2}^{2+}$ is too low $(<1 \%)$ to affect the data reported herein [2a].

Another concern in performing collisional relaxation experiments in an ICR ion cell is the $z$-axis component of kinetic energy as a result of the trapping voltage used to constrain ions. We examined the ion chemistry reported herein over a range of trapping voltages ( 1 to $6 \mathrm{~V})$ and found no significant effect $( \pm 10 \%)$ on the charge-exchange ion-molecule reaction chemistry of the $\mathrm{Fe}^{+}$collisional relaxation process. This observation is also in agreement with previous studies that probed the effect of trapping voltage on relative abundances of metastable electronic states of $\mathrm{Fe}^{+}$formed by $\mathrm{EI}$ of $\mathrm{Fe}(\mathrm{CO})_{5}$ [2a].

It is also important to show that the $\mathrm{Fe}(\mathrm{CO})_{y}^{+}$ charge-exchange product ions are indeed formed by charge exchange and not by ligand exchange--substitution reactions. We demonstrated this by mass selection of the ${ }^{54} \mathrm{Fe}^{+}$isotope $(\sim 4 \%$ relative abundance) and reaction of it with $\mathrm{Fe}(\mathrm{CO})_{5}\left(92 \%{ }^{56} \mathrm{Fe}\right)$. These experiments showed that the $\mathrm{Fe}(\mathrm{CO})_{y}^{+}$product ions have the same isotopic distribution ${ }^{54} \mathrm{Fe}:{ }^{56} \mathrm{Fe}:{ }^{57} \mathrm{Fe}$ as the reactive $\mathrm{Fe}(\mathrm{CO})_{5}(6: 92: 2)$.

$\mathrm{Fe}(\mathrm{CO})_{5}$ samples were obtained from commercially available sources (Strem Chemical Inc.). Nitric oxide, methane, hydrogen, carbon monoxide, and krypton were obtained from Matheson Gas Products, Inc. (MGP) (East Rutherford, NJ). Helium and argon were purchased from AIRCO, deuterium was obtained from MSD Isotopes, Division of Merck Frosst Canada Inc., and methanol was obtained from Mallinckrodt (St. Louis, MO). Sample preparation involved freezing the $\mathrm{Fe}(\mathrm{CO})_{5}$ and $\mathrm{CH}_{3} \mathrm{OH}$ samples in liquid nitrogen and pumping out air and other noncondensable gases for a period of a few minutes. All other samples were used as received without further purification; the sample purity was verified by examination of the $70-\mathrm{eV}$ electron impact ionization mass spectra of each reagent gas. Sample purities were as follows: carbon monoxide commercial purity (minimum 99.5\%), methane ultrahigh purity $(99.97 \%)$, krypton research grade $(99.995 \%)$, deuterium (99.9\%), helium and nitrogen (99.995\%), argon (99.998\%), hydrogen (99.99\%), and methanol spectrophotometric grade $(99.8 \%)$. The listed minimum commercial purity of nitric oxide is $99.0 \%$; however, electron impact data revealed that the homogeneity of the NO sample is dependent on the extent of exposure to $\mathrm{O}_{2}$ and light [2a]. The primary contaminants of $\mathrm{NO}$ are $\mathrm{N}_{2}, \mathrm{~N}_{2} \mathrm{O}$, and $\mathrm{NO}_{2}$, but the amount of each impurity can be minimized by careful control of exposure to $\mathrm{O}_{2}$ and light. The buildup of impurity was monitored (by EI mass spectrometry) during the course of all experiments. If the ion signals for $\mathrm{N}_{2}, \mathrm{~N}_{2} \mathrm{O}$, or $\mathrm{NO}_{2}$ increased to $5 \%$ relative abundance or greater the experiments were interrupted and the NO gas was purged.

Collisional relaxation rate constants were calculated in the following manner. First, all ion abundances were calculated from integrated peak areas. The calculated ion abundances for the reactant $\mathrm{Fe}^{+}$and.all product ions were then summed for each spectrum, and each ion in the spectrum was normalized to the total ion signal $\left(I m_{\mathrm{j}} / \Sigma I m_{\mathrm{i}}\right)$. The normalized ion abundances at time $t_{\mathrm{i}}$ were then divided by their respective intensities at zero collisional relaxation time $\left(t_{0}\right):\left[\left(I m_{\mathrm{i}} /\right.\right.$ $\left.\left.\sum I m_{\mathrm{i}}\right) t_{\mathrm{i}} /\left(I m_{\mathrm{i}} / \sum I m_{\mathrm{i}}\right) t_{0}\right]$

Collisional relaxation rates were calculated by using a "simplex" nonlinear least-squares fitting routine [17]. Details concerning this program have been described elsewhere [18]. Pressure readings for each quenching reagent were corrected for ionization gauge sensitivity according to the method described by Bartmess and Georgiadis [19].

\section{Results}

The ion-molecule reaction chemistry of $\mathrm{Fe}^{+}$with $\mathrm{Fe}(\mathrm{CO})_{5}$ was presented in previous papers [5]. Briefly, $\mathrm{Fe}^{+}$reacts with neutral $\mathrm{Fe}(\mathrm{CO})_{5}$ according to reactions 1-8:

$$
\begin{aligned}
\mathrm{Fe}^{+}+\mathrm{Fe}(\mathrm{CO})_{5} \stackrel{\mathrm{Fe}(\mathrm{CO})_{5}^{+}+\mathrm{Fe}}{\longrightarrow} & \mathrm{Fe}(\mathrm{CO})_{4}^{+}+\mathrm{Fe}+\mathrm{CO} \\
& \left.\mathrm{Fe}(\mathrm{CO})_{3}^{+}+\mathrm{Fe}+2 \mathrm{CO}\right)_{2}^{+}+\mathrm{Fe}+3 \mathrm{CO} \\
& \mathrm{Fe}(\mathrm{CO})^{+}+\mathrm{Fe}+4 \mathrm{CO} \\
& \mathrm{Fe}_{2}(\mathrm{CO})_{2}^{+}+3 \mathrm{CO} \\
& \mathrm{Fe}_{2}(\mathrm{CO})_{3}^{+}+2 \mathrm{CO} \\
& \mathrm{Fe}_{2}(\mathrm{CO})_{4}^{+}+\mathrm{CO}
\end{aligned}
$$

Reactions 1-5 are nondissociative and dissociative charge-transfer reactions and reactions 6-8 are condensation or clustering reactions [20]. The charge-transfer products (reactions 1-5) and the ionic cluster fragments $\mathrm{Fe}_{2}(\mathrm{CO})_{2}^{+}$and $\mathrm{Fe}_{2}(\mathrm{CO})_{3}^{+}$are formed by reactions of electronically excited metastable states of $\left(\mathrm{Fe}^{+}\right)^{*}$, whereas the $\mathrm{Fe}_{2}(\mathrm{CO})_{4}^{+}$ionic cluster fragment is 
formed exclusively by reactions of $\left(\mathrm{Fe}^{+}\right)^{\circ}$. The electronic states that give rise to these reactions are listed in Table 1. The ionization energy $(7.92 \mathrm{eV})$ of $\mathrm{Fe}^{+}$is the average over the spin-orbit levels rather than the adiabatic value of $7.90 \mathrm{eV}$. The thermochemical data for $\mathrm{Fe}^{+}$are taken from Garstang [21] and the appearance energies for the charge-transfer product ions are based on photodissociation measurements [22]. The thermochemical data are in reasonable agreement with recent measurements by Norwood et al. [23] with the possible exception of $\mathrm{FeCO}^{+}$. We have some doubts as to whether $\mathrm{FeCO}^{+}$is formed in the ground state or a long-lived excited species [24]; therefore the appearance energy value for $\mathrm{FeCO}^{+}$listed in Table 1 is taken from Rosenstock et al. rather than the value reported by Norwood.

In this paper, we present results of studies on bimolecular collisional relaxation of $\left(\mathrm{Fe}^{+}\right)^{*}$. The relative abundances of $\left(\mathrm{Fe}^{+}\right)^{\circ}$ and $\left(\mathrm{Fe}^{+}\right)^{*}$ states are measured by using the clustering and charge-exchange ionmolecule reaction product ion distributions [5]. The abundances of product ions $\left[\mathrm{Fe}(\mathrm{CO})_{y}^{+}\right.$and/or $\left.\mathrm{Fe}_{2}(\mathrm{CO})_{y}^{+}\right]$from reaction of $\left(\mathrm{Fe}^{+}\right)^{*}$ and the neutral $\mathrm{Fe}(\mathrm{CO})_{5}$ are measured before and after $\left(\mathrm{Fe}^{+}\right)^{*}$ is allowed to react with the collision gas (see Experimental section). For example, the ${ }^{4} \mathrm{~F} \mathrm{Fe}^{+}$reacts with $\mathrm{Fe}(\mathrm{CO})_{5}$ to form the $\mathrm{Fe}(\mathrm{CO})_{5}^{+}$charge-transfer product ion. The rate of collisional relaxation of the ${ }^{4} F \mathrm{Fe}^{+}$state is determined by measuring the rate of disappearance of the $\mathrm{Fe}(\mathrm{CO})_{5}^{+}$charge-transfer product ion following collisional relaxation of the reactant $\left(\mathrm{Fe}^{+}\right)^{*}$ with selected collision gases. Likewise, the collisional relaxation rates of ions in higher lying excited states can be determined by measuring the rates of disappearance of ionic charge-transfer products $\left[\mathrm{Fe}(\mathrm{CO})_{y}^{+}\right]$with energies that correspond to those states. The $\mathrm{Fe}(\mathrm{CO})_{y}^{+}$chargeexchange product ions can be formed by several different $\left(\mathrm{Fe}^{+}\right)^{*}$ ions; thus, the measured decay rates provide information on the reactivity of all ions that react to give a particular product ion. In a previous paper, we presented arguments that the $\mathrm{Fe}(\mathrm{CO})_{y}^{+}$ product ion abundances can be used to bracket the energies of the reacting $\left(\mathrm{Fe}^{+}\right)^{*}$ ions. The same assumptions are presumed valid for this work as well (vide infra).

Collisional relaxation of $\left(\mathrm{Fe}^{+}\right)^{*}$ by $\mathrm{He}, \mathrm{Ar}, \mathrm{Kr}, \mathrm{H}_{2}$, ${ }^{2} \mathrm{H}_{2}, \mathrm{~N}_{2}, \mathrm{CO}, \mathrm{CO}_{2}, \mathrm{NO}, \mathrm{CH}_{4}$, and $\mathrm{CH}_{3} \mathrm{OH}$ was examined. Figures 1-5 contain plots of the log relative abundances $\left(I / I_{0}\right)$ of $\mathrm{Fe}(\mathrm{CO})_{y}^{+}$charge-transfer product ions as a function of reaction time (residence time in region 2) between $\left(\mathrm{Fe}^{+}\right)^{*}$ and $\mathrm{He}, \mathrm{Ar}, \mathrm{H}_{2}, \mathrm{CO}$, and $\mathrm{CH}_{4}$, respectively. Although the data for each collision

Table 1. Ionization energies of selected electronic states of $\mathrm{Fe}^{+}$, the appearance energies of the charge-transfer product ions, and the relative abundances of excited states of $\mathrm{Fe}^{+}[70-50-\mathrm{eV} \mathrm{EI}$ of $\mathrm{Fe}(\mathrm{CO})_{5}$ ] estimated from the charge-transfer ion-molecule reaction chemistry data

\begin{tabular}{|c|c|c|c|c|c|}
\hline State & Configuration & $\begin{array}{c}\text { Ionization } \\
\text { energy } \\
(\mathrm{eV})\end{array}$ & $\begin{array}{c}\text { Appearance } \\
\text { energy } \\
(\mathrm{eV})\end{array}$ & $\begin{array}{l}\text { Charge- } \\
\text { transfer } \\
\text { product }\end{array}$ & $\begin{array}{c}\text { Excited } \\
\text { states, } \\
\text { relative } \\
\text { abundance } \\
(\%)\end{array}$ \\
\hline \multirow[t]{2}{*}{$\overline{{ }^{2} G}$} & $4 s^{1} 3 d^{6}$ & 11.64 & & & 10 \\
\hline & & & 11.53 & $\mathrm{Fe}(\mathrm{CO})^{+}$ & \\
\hline${ }^{2} F$ & $4 s^{1} 3 d^{8}$ & 11.26 & & & \\
\hline${ }^{2} H$ & $4 s^{1} 3 d^{6}$ & 11.12 & & & \\
\hline${ }^{2} p$ & $4 s^{1} 3 d^{6}$ & $11.07\}$ & & & 10 \\
\hline${ }^{4} G$ & $4 s^{1} 3 d^{6}$ & 11.02 & & & \\
\hline${ }^{8} S$ & $4 s^{2} 3 d^{5}$ & 10.76 & & & \\
\hline${ }^{4} \mathrm{~F}$ & $4 s^{1} 3 d^{6}$ & 10.68 & 10.68 & $\mathrm{Fe}(\mathrm{CO})_{2}^{+}$ & \\
\hline${ }^{4} H$ & $4 s^{1} 3 d^{6}$ & 10.51 & & & \\
\hline${ }^{4} p$ & $4 s^{1} 3 d^{6}$ & 10.45 & & & \\
\hline${ }^{2} D$ & $3 d^{7}$ & $10.42\}$ & & & 10 \\
\hline${ }^{2} H$ & $3 d^{7}$ & 10.39 & & & \\
\hline \multirow[t]{2}{*}{${ }^{2} P$} & $3 d^{7}$ & 10.17 & & & \\
\hline & & & 9.87 & $\mathrm{Fe}(\mathrm{CO})_{3}^{+}$ & \\
\hline $\begin{array}{l}{ }^{2} G \\
{ }^{4} P\end{array}$ & $\begin{array}{l}3 d^{7} \\
3 d^{7}\end{array}$ & $\left.\begin{array}{l}9.86 \\
9.56\end{array}\right\}$ & & & 30 \\
\hline \multirow[t]{2}{*}{${ }^{4} D$} & $4 s^{1} 3 d^{6}$ & 8.90 & & & \\
\hline & & & 8.77 & $\mathrm{Fe}\left(\mathrm{CO}_{4}^{+}\right)$ & \\
\hline \multirow[t]{2}{*}{${ }^{4} F$} & $3 d^{7}$ & 8.17 & & & 40 \\
\hline & & & 7.98 & $\left.\mathrm{Fe}(\mathrm{CO})_{5}^{+}\right)$ & \\
\hline${ }^{6} D$ & $4 s^{1} 3 d^{6}$ & 7.92 & & & \\
\hline
\end{tabular}




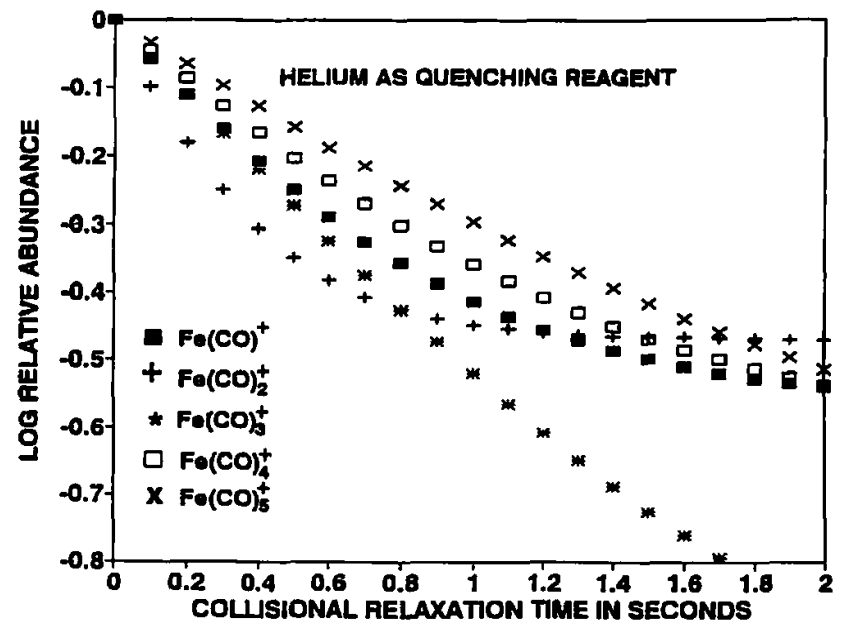

Figure 1. A plot of log normalized relative abundance $\left(I / I_{0}\right)$ of $\mathrm{Fe}(\mathrm{CO})_{y}^{+}$charge-transfer product ions as a function of reaction time between $\mathrm{Fe}^{+}$[produced by $70-\mathrm{eV}$ electron impact of $\left.\mathrm{Fe}(\mathrm{CO})_{5}\right]$ and $\mathrm{He}$. The $\mathrm{Fe}(\mathrm{CO})_{y}^{+}$charge-transfer product ions are formed by reactions of $\left(\mathrm{Fe}^{+}\right)^{*}$ with $\mathrm{Fe}(\mathrm{CO})_{5}$ and are used to bracket the energies of $\left(\mathrm{Fe}^{+}\right)^{*}$ before and after collisional relax-

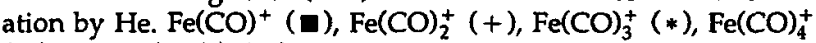
$(\square)$, and $\mathrm{Fe}(\mathrm{CO})_{5}^{+}(\mathrm{x})$.

gas are similar, there are notable differences. For example, the collisional relaxation data for $\mathrm{He}$ and $\mathrm{Ar}$ show that the relative abundance of $\mathrm{Fe}(\mathrm{CO})_{y}^{+}$charge-transfer product ions are continually depleted during the entire reaction time. Note, however, that a significant fraction of the $\left(\mathrm{Fe}^{+}\right)^{*}$ ions that give rise to $\mathrm{Fe}(\mathrm{CO})_{y}^{+}(y=1$, 2 , and 4) react very slowly and the ion population levels off after approximately $1 \mathrm{~s}$.

Figure 6 contains plots of the abundances of $\mathrm{Fe}_{2}(\mathrm{CO})_{4}^{+}$ionic cluster fragments formed by reaction 8 as a function of collisional relaxation time of $\left(\mathrm{Fe}^{+}\right)^{*}$ with various reagents. The abundance of $\mathrm{Fe}_{2}(\mathrm{CO})_{4}^{+}$ ionic cluster fragments increases as $\left(\mathrm{Fe}^{+}\right)^{*}$ is collision-

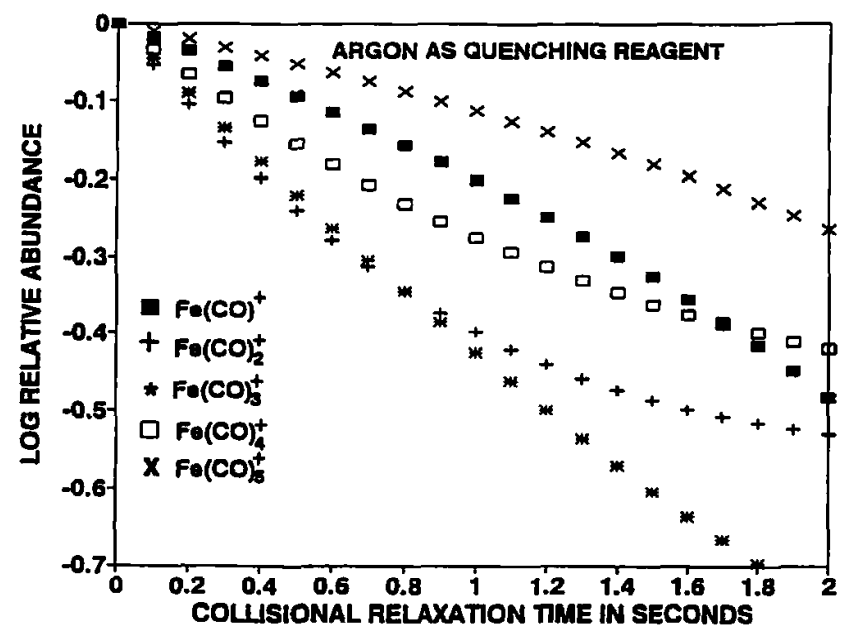

Figure 2. A plot of log normalized relative abundance $\left(I / I_{0}\right)$ of $\mathrm{Fe}(\mathrm{CO})_{y}^{+}$charge-transfer product ions (reactions 1-5) [5] as a function of reaction time between $\mathrm{Fe}^{+}[70-\mathrm{eV}$ electron impact of $\left.\mathrm{Fe}(\mathrm{CO})_{5}\right]$ and $\mathrm{Ar}$. $\mathrm{Fe}(\mathrm{CO})^{+}(\mathbb{E}), \mathrm{Fe}(\mathrm{CO})_{2}^{+}(+), \mathrm{Fe}(\mathrm{CO})_{3}^{+}(*)$, $\mathrm{Fe}(\mathrm{CO})_{4}^{+}(\square)$, and $\mathrm{Fe}(\mathrm{CO})_{5}^{+}(x)$.

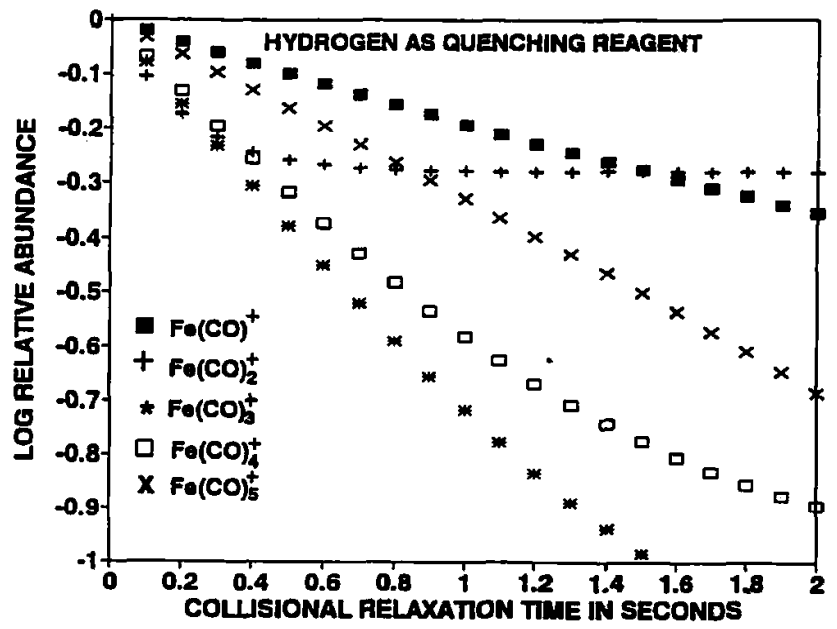

Figure 3. A plot of log normalized relative abundance $\left(I / I_{0}\right)$ of $\mathrm{Fe}(\mathrm{CO})_{y}^{+}$charge-transfer product ions (reactions $\left.1-5\right)$ as a function of reaction time between the reactant $\mathrm{Fe}^{+}[70-\mathrm{eV}$ electron impact of $\left.\mathrm{Fe}(\mathrm{CO})_{5}\right]$ and $\mathrm{H}_{2}$. The $\mathrm{Fe}(\mathrm{CO})_{y}^{+}$charge-transfer product ions are formed by reaction of $\mathrm{Fe}^{+}$with $\mathrm{Fe}(\mathrm{CO})_{5}$. $\mathrm{Fe}(\mathrm{CO})^{+}$ (a), $\mathrm{Fe}(\mathrm{CO})_{2}^{+}(+), \mathrm{Fe}(\mathrm{CO})_{3}^{+}(*), \mathrm{Fe}(\mathrm{CO})_{4-}^{+}(\mathrm{D})$, and $\mathrm{Fe}(\mathrm{CO})_{5}^{+}$ $(x)$.

ally relaxed, whereas the abundances (not shown) of $\mathrm{Fe}_{2}(\mathrm{CO})_{2}^{+}$and $\mathrm{Fe}_{2}(\mathrm{CO})_{3}^{+}$ionic cluster fragments decrease as $\left(\mathrm{Fe}^{+}\right)^{*}$ is collisionally relaxed. The rate at which the $\mathrm{Fe}_{2}(\mathrm{CO})_{4}^{+}$ionic cluster fragment population increases depends upon the collisional relaxation reagent used. For example, when $\mathrm{NO}$ or $\mathrm{CH}_{3} \mathrm{OH}$ is used as the quenching reagent, the abundance of $\mathrm{Fe}_{2}(\mathrm{CO})_{4}^{+}$increases during the first $500 \mathrm{~ms}$ and remains constant at longer collisional relaxation times. Conversely, the abundance of $\mathrm{Fe}_{2}(\mathrm{CO})_{4}^{+}$increases steadily during the entire collisional relaxation time

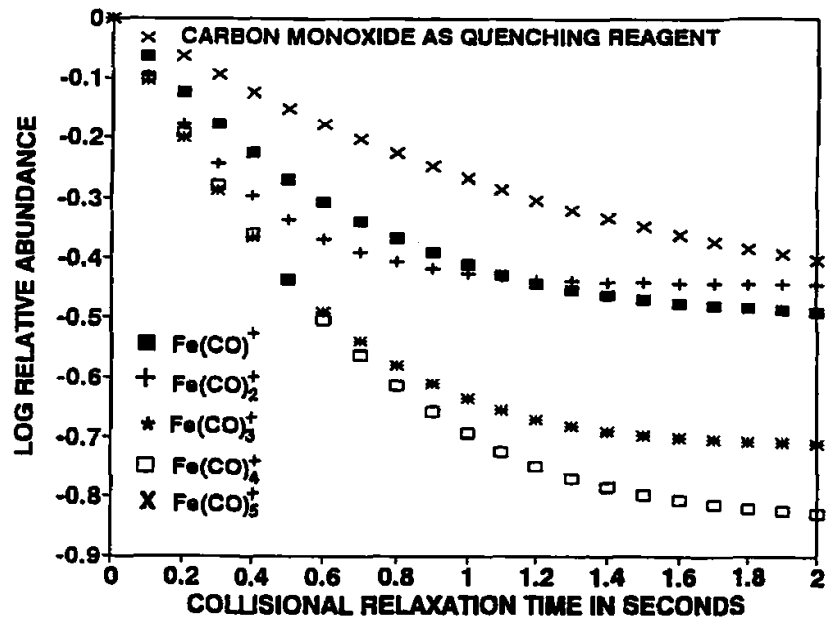

Figure 4. A plot of log normalized relative abundance $\left(I / I_{0}\right)$ of $\mathrm{Fe}(\mathrm{CO})_{y}^{+}$charge-transfer product ions (reactions $\left.1-5\right)$ as a function of reaction time between the reactant $\mathrm{Fe}^{+}[70-\mathrm{eV}$ electron impact of $\left.\mathrm{Fe}(\mathrm{CO})_{5}\right]$ and $\mathrm{CO}$. The $\mathrm{Fe}(\mathrm{CO})_{y}^{+}$charge-transfer product ions are formed by reaction of $\mathrm{Fe}^{+}$with $\mathrm{Fe}(\mathrm{CO})_{5} . \mathrm{Fe}(\mathrm{CO})^{+}$ $(\mathrm{a}), \mathrm{Fe}(\mathrm{CO})_{2}^{+}(+), \mathrm{Fe}(\mathrm{CO})_{3}^{+}(*), \mathrm{Fe}(\mathrm{CO})_{4}^{+}(\square)$, and $\mathrm{Fe}(\mathrm{CO})_{5}^{+}$ $(x)$. 


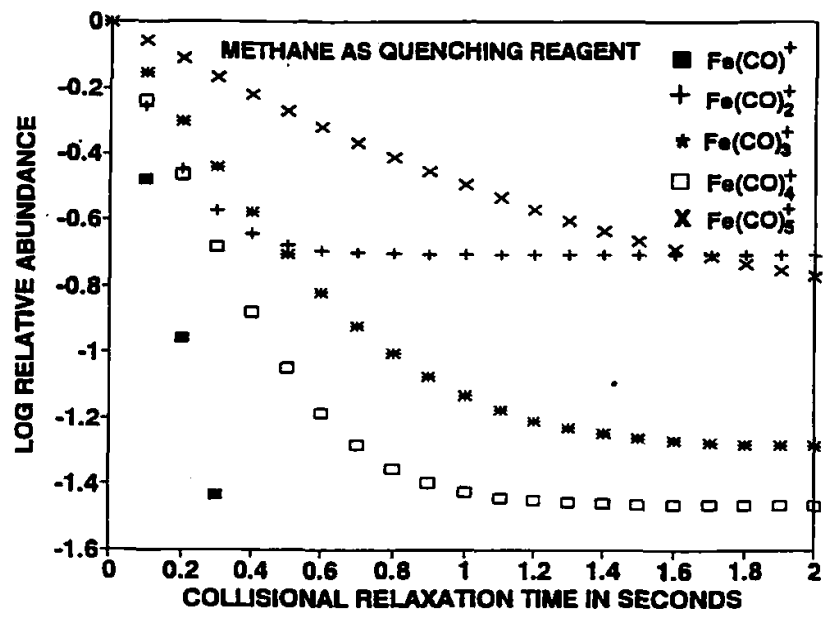

Figure 5. A plot of log normalized relative abundance $\left(I / I_{0}\right)$ of $\mathrm{Fe}(\mathrm{CO})_{y}^{+}$charge-transfer product ions (reactions $\left.1-5\right)$ as a function of reaction time between the reactant $\mathrm{Fe}^{+}[70 \mathrm{eV}$ electron impact of $\mathrm{Fe}(\mathrm{CO})_{5}$ ] and $\mathrm{CH}_{4}$. The $\mathrm{Fe}(\mathrm{CO})_{y}^{+}$charge-transfer product ions are formed by reaction of $\mathrm{Fe}^{+}$with $\mathrm{Fe}(\mathrm{CO})_{5} . \mathrm{Fe}(\mathrm{CO})^{+}$ $(\mathrm{E}), \mathrm{Fe}(\mathrm{CO})_{2}^{+}(+), \mathrm{Fe}(\mathrm{CO})_{3}^{+}(*), \mathrm{Fe}(\mathrm{CO})_{4}^{+}(\square)$, and $\mathrm{Fe}(\mathrm{CO})_{5}^{+}$ $(x)$.

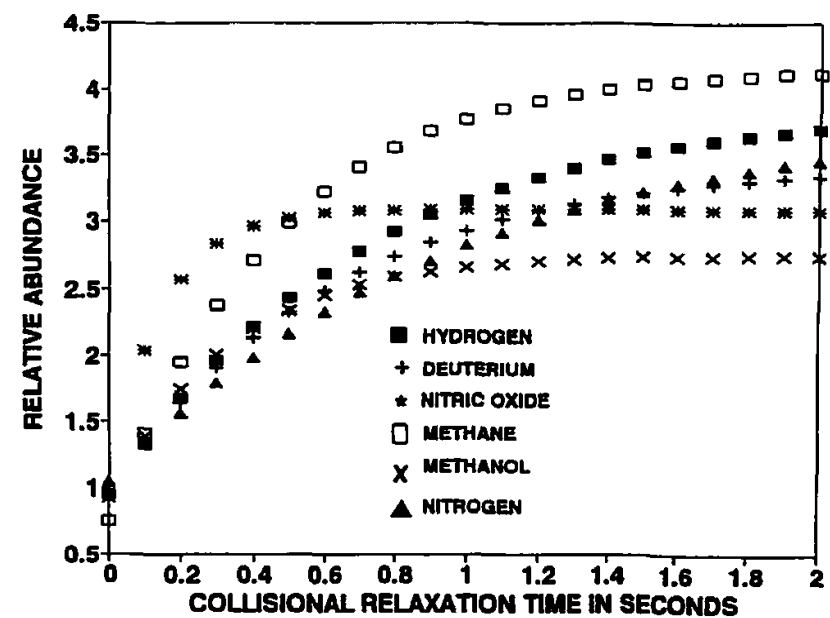

Figure 6. A plot of the normalized relative abundance of $\mathrm{Fe}_{2}(\mathrm{CO})_{4}^{+}$ionic cluster fragment (reaction 8) as a function of reaction time between the reactant $\mathrm{Fe}^{+}[70-\mathrm{eV}$ electron impact of $\left.\mathrm{Fe}(\mathrm{CO})_{5}\right]$ and various reagents. (a) $\mathrm{H}_{2}(\mathrm{E}),{ }^{2} \mathrm{H}_{2}(+)$, NO (*), $\mathrm{CH}_{4}(\square), \mathrm{CH}_{3} \mathrm{OH}(\times)$, and $\mathrm{N}_{2}(\Delta) ;(b) \mathrm{He}(\mathbf{a}), \mathrm{Ar}(+), \mathrm{Kr}(*)$, and $C O(\square)$. when $\mathrm{H}_{2},{ }^{2} \mathrm{H}_{2}, \mathrm{~N}_{2}, \mathrm{CO}$ (not shown), or $\mathrm{CH}_{4}$ is used as the collision gas.

The rate constants for the disappearance of $\mathrm{Fe}(\mathrm{CO})_{y}^{+}$ charge-transfer ionic products and for the formation of $\mathrm{Fe}_{2}(\mathrm{CO})_{4}^{+}$ionic cluster fragments following collisional relaxation of $\left(\mathrm{Fe}^{+}\right)^{*}$ with various reagents are summarized in Table 2 . The rate constants listed in Table 2 correspond to the rate of depletion of $\mathrm{Fe}(\mathrm{CO})_{y}^{+}$ charge-transfer product ions that are reactive over the period of 100-200 ms following collisional relaxation. We have not attempted to determine rate constants for the slowly reacting population (reaction time $>200 \mathrm{~ms}$ ).

\section{Discussion}

A major objective of the current work is to develop a semiquantitative method to bracket the energies of $\left(\mathrm{Fe}^{+}\right)^{*}$ ions that are reacted with functionalized organic molecules, for example, small molecules that can serve as models for peptides. For example, we examined the reactions of $\mathrm{Fe}^{+}$[formed by $\mathrm{EI}$ of $\mathrm{Fe}(\mathrm{CO})_{5}$ ] with formamides and acetamides and found that the product ions formed depend upon the energy (electron configuration) of the reacting metal ion [25]. The next step is to ascertain whether the reaction chemistry of $\mathrm{Fe}^{+}$ions can be used to provide specific structural information about the neutral reactant. The approach for these studies is to use collisional relaxation chemistry to select $\left(\mathrm{Fe}^{+}\right)^{*}$ with a particular range of energies and allow the ions to react with the neutral of interest; therefore, the ion population sampled in this manner will be composed of $\left(\mathrm{Fe}^{+}\right)^{\circ}$ and the desired $\left(\mathrm{Fe}^{+}\right)^{*}$ ions that are unreactive or slowly reacting with the relaxation reagent. Thus, an important objective of this study is to determine which $\left(\mathrm{Fe}^{+}\right)^{*}$ ions and what fraction survive reactions with the various relaxation reagents.

The bimolecular collisional relaxation data for $\left(\mathrm{Fe}^{+}\right)^{*}$ presented in this paper are taken from (1) charge-exchange ion-molecule reaction chemistry of $\mathrm{Fe}(\mathrm{CO})_{y}^{+}$decay curves and their relationship to $\left(\mathrm{Fe}^{+}\right)^{*}$, (2) reaction pathways that involve $\left(\mathrm{Fe}^{+}\right)^{*}$ that are in competition with the collisional relaxation processes, (3) relative efficiency of collisional relaxation of $\left(\mathrm{Fe}^{+}\right)^{*}$

Table 2. The rate constants $k\left[\left(\mathrm{~cm}^{3} / \mathrm{s}\right) \times 10^{-10}\right]$ for the disappearance of $\mathrm{Fe}(\mathrm{CO})_{y}^{+}$and the formation of $\mathrm{Fe}_{2}(\mathrm{CO})_{4}^{+}$following collisional relaxation of $\left(\mathrm{Fe}^{+}\right)^{*}$ with various reagents

\begin{tabular}{llllcccccc}
\hline $\mathrm{Fe}\left(\mathrm{CO}_{7}\right)^{+}$ & Helium & Argon & Krypton & Hydrogen & Deuterium & Methanol & Nitrogen & $\begin{array}{c}\text { Nitric } \\
\text { oxide }\end{array}$ & $\begin{array}{c}\text { Carbon } \\
\text { monoxide }\end{array}$ \\
\hline \hline$y=5$ & 0.029 & 0.032 & 0.018 & 0.48 & 0.60 & 4.3 & 1.2 & 5.8 & 1.9 \\
$y=4$ & 0.42 & 2.3 & 3.6 & 1.2 & 0.88 & 5.0 & 2.3 & 8.4 & 4.6 \\
$y=3$ & 0.44 & 2.3 & 2.7 & 1.3 & 1.0 & 5.8 & 2.4 & 14 & 5.2 \\
$y=2$ & 1.1 & 3.6 & 8.1 & 4.0 & 3.7 & 23 & 6.0 & - & 6.3 \\
$y=1$ & 0.57 & 0.40 & 3.9 & 0.39 & 0.27 & 5.7 & 2.7 & 13 & 3.8 \\
$\mathrm{Fe}_{2}(\mathrm{CO})_{4}^{+}$ & 0.31 & 2.0 & 1.9 & 0.97 & 0.98 & 7.7 & 1.6 & 9.2 & 1.8 \\
\hline
\end{tabular}


by various reagents, and (4) the collisional relaxation mechanisms.

\section{Basic Assumptions and Limitations of Charge-Exchange Ion-Molecule Reactions to Probe Energies of Reactant Ions}

In the studies described herein, we use the abundances of charge-exchange ion-molecule product ions to "read" the internal energies of the reactant $\mathrm{Fe}^{+}$ions. The use of charge-exchange ion-molecule reactions to measure abundances and energies of $\left(\mathrm{Fe}^{+}\right)^{*}$ ions requires that certain fundamental assumptions be made. Of key importance is whether the $\left(\mathrm{Fe}^{+}\right)^{*}$ ions react to form the lowest energy charge-exchange product ions or react via channels that result in the lowest energy difference $(\Delta E)$ between reactant states and ionic products. In an earlier paper, we examined this question and argued that the high lying states that react to form the $\mathrm{Fe}(\mathrm{CO})^{+}$ion do not react to form other product ions; for example, once the precursor to $\mathrm{Fe}(\mathrm{CO})_{3}^{+}$has reacted away, other $\left(\mathrm{Fe}^{+}\right)^{*}$ ions do not react to form this product (see Figures 1-3). In addition, the high lying $\left(\mathrm{Fe}^{+}\right)^{*}$ ions that react to form $\mathrm{Fe}(\mathrm{CO})_{2}^{+}$are not depleted by reaction with $\mathrm{NO}$; these ions react with $\mathrm{Fe}(\mathrm{CO})_{5}$ to form only $\mathrm{Fe}(\mathrm{CO})_{2}^{+}[2 \mathrm{a}$. Clearly these $\left(\mathrm{Fe}^{+}\right)^{*}$ have sufficient energy to form $\mathrm{Fe}(\mathrm{CO})_{y}^{+}(y=3-5)$, but react via a single reaction channel. Photodissociation studies of $\mathrm{Fe}(\mathrm{CO})_{y}^{+}$ions show high selectivity in terms of product ions [26]. For example, the only photofragment ion of $\left[\mathrm{Fe}(\mathrm{CO})_{4}^{+}\right]^{*}$, formed by photoexcitation at 458-524.5 nm (2.71-2.41 $\mathrm{eV})$, is $\mathrm{Fe}(\mathrm{CO})_{2}^{+}$. Clearly, the $\left[\mathrm{Fe}(\mathrm{CO})_{4}^{+}\right]^{*}$ ion has sufficient energy to produce $\mathrm{Fe}(\mathrm{CO})_{3}^{+}$, but the excess energy $(\sim 0.81 \mathrm{eV})$ must be partitioned as energy of translation or internal energy of the photofragment of the ion and neutral. Lastly, $\left(\mathrm{Fe}^{+}\right)^{*}$ formed at low ionizing energy reacts with $\mathrm{Fe}(\mathrm{CO})_{5}$ to form a greater amount of $\mathrm{Fe}(\mathrm{CO})_{y}^{+}(y=1-2)$ relative to the $y=3-5$ ions (see Figure 2 in ref 5). This observation has two implications: (1) at low ionizing beam energy, high lying $\left(\mathrm{Fe}^{+}\right)^{*}$ ions are formed in greater abundance than are the low energy ions and (2) the high lying $\left(\mathrm{Fe}^{+}\right)^{*}$ states react to form the high energy chargeexchange product ions.

The rationale we use to explain the selectivity of the charge-exchange reaction is to consider ion product formation as a two-step process, reaction 9. The fragment ions formed by dissociation of the $\left[\left(\mathrm{Fe}(\mathrm{CO})_{5}\right)^{+}\right]^{*}$ are determined by the internal energy content of the precursor ion. However, if two product ions are energetically accessible, formation of the lower energy product ion requires that a greater amount of the excess energy be partitioned as translational energy or retained as internal energy of the ionic and neutral fragments.

$$
\begin{aligned}
\left(\mathrm{Fe}^{+}\right)^{*}+\mathrm{Fe}(\mathrm{CO})_{5} & \rightarrow \mathrm{Fe}^{\circ}+\left[\left(\mathrm{Fe}(\mathrm{CO})_{5}\right)^{+}\right]^{*} \\
& \rightarrow \mathrm{Fe}(\mathrm{CO})_{y}^{+}+(5 y) \mathrm{CO}
\end{aligned}
$$

Effect of Ionic Products Formed by $\left(\mathrm{Fe}^{+}\right) *$ on Collisional Relaxation Rate Constants

An important consideration for determination of the rate constants for the collisional relaxation of $\left(\mathrm{Fe}^{+}\right)^{*}$ is to differentiate between the ionic product channels and collisional relaxation reactions. Collisional relaxation of $\left(\mathrm{Fe}^{+}\right)^{*}$ by $\mathrm{He}, \mathrm{Ar}$, and $\mathrm{Kr}$ is not affected by highly endoergic charge-exchange reactions (ionization energies: $\mathrm{He}=24.6 \mathrm{eV}$ [27], $\mathrm{Ar}=15.76^{\circ} \mathrm{eV}$ [8], and $\mathrm{Kr}=$ $14.00 \mathrm{eV}$ [28]). Therefore, in the reaction of $\left(\mathrm{Fe}^{+}\right)^{*}$ with $\mathrm{He}, \mathrm{Ar}$, and $\mathrm{Kr}$ the rate of disappearance of $\mathrm{Fe}(\mathrm{CO})_{y}^{+}$is a direct measure of collisional relaxation. Reactions of $\left(\mathrm{Fe}^{+}\right)^{*}$ with $\mathrm{N}_{2}$ or $\mathrm{CO}$ do not yield any detectable products because $\mathrm{N}-\mathrm{N}$ and $\mathrm{C}-\mathrm{O}$ bond activation is highly endothermic; therefore, the abundance of the charge-transfer product ions formed following the reaction of $\left(\mathrm{Fe}^{+}\right)^{*}$ with $\mathrm{N}_{2}$ or $\mathrm{CO}$ provides a direct measure of the collisional relaxation rate.

The $\left(\mathrm{Fe}^{+}\right)^{*}$ ions react with NO by collisional relaxation to form ${ }^{6} \mathrm{D}\left(\mathrm{Fe}^{+}\right)^{*}$ and ${ }^{6} \mathrm{~S}\left(\mathrm{Fe}^{+}\right)^{*}$. ions, by chargetransfer reactions to form $\mathrm{NO}^{+}$, and by associative reaction to form $\mathrm{Fe}^{+}(\mathrm{NO})$ [2a]. Thus, the disappearance rate of $\mathrm{Fe}^{+}$in reactions with NO gives a measure of product-forming [e.g., $\mathrm{NO}^{+}$and $\mathrm{Fe}^{+}(\mathrm{NO})$ ] and collisonal relaxation channels. Conversely, monitoring the rate of disappearance of $\mathrm{Fe}(\mathrm{CO})_{y}^{+}$(formed by reactions $1-5)$ as a function of reaction time between $\left(\mathrm{Fe}^{+}\right)^{*}$ and NO provides a direct measurement for the rate of disappearance of $\left(\mathrm{Fe}^{+}\right)^{*}$ ions that have a specific range of energies. Collisional relaxation of high lying $\left(\mathrm{Fe}^{+}\right)^{*}$ states (energies greater than $9.26 \mathrm{eV}$ ) by NO competes with the charge-transfer reaction (to form $\mathrm{NO}^{+}$). However, the $4 s^{1} 3 d^{6}\left(\mathrm{Fe}^{+}\right)^{*}$ ions with ionization energies greater than $10.71 \mathrm{eV}$ react with NO predominately to form the $4 s^{2} 3 d^{5}\left(\mathrm{Fe}^{+}\right)^{*}$ ion, whereas the chargetransfer reaction proceeds (determined by the rate of $\mathrm{NO}^{+}$formation) at approximately $50 \%$ the overall rate for the depletion of the ${ }^{4} D,{ }^{4} P$, and ${ }^{2} G\left(\mathrm{Fe}^{+}\right)^{*}$ ion [29]. On the other hand, collisional relaxation of the $\left(\mathrm{Fe}^{+}\right)^{*}$ states below $9.26 \mathrm{eV}$ does not compete with the charge-transfer channel because $\left(\mathrm{Fe}^{+}\right)^{*}$ ions in these states do not have sufficient energy to undergo charge transfer with NO (ionization energy $=9.26 \mathrm{eV}$ ) [30].

Armentrout and co-workers [31] reported that $\left(\mathrm{Fe}^{+}\right)^{*}$ reacts with $\mathrm{CH}_{4}$ to form $\mathrm{FeH}^{+}$and $\mathrm{FeCH}_{3}^{+}$, but these products are only observed as minor products ( $\sim 1 \%$ relative abundance) in the ICR experiments. The reactions that give rise to these products are endothermic by approximately $2 \mathrm{eV}$ for ground state $\left(\mathrm{Fe}^{+}\right)^{\circ}$. Because the relative abundances $(\sim 1 \%)$ of $\mathrm{FeH}^{+}$and $\mathrm{FeCH}_{3}^{+}$product ions are small, we do not expect these reactions to contribute significantly to the depletion of $\left(\mathrm{Fe}^{+}\right)^{*}$. Thus, depletion of $\left(\mathrm{Fe}^{+}\right)^{*}$ in reaction with $\mathrm{CH}_{4}$ is attributed to the collisional relaxation process.

The $\mathrm{FeOH}^{+}$is the only product ion (rate constant $8 \times 10^{-11} \mathrm{~cm}^{3} \mathrm{~s}^{-1}$ ) [2h] detected in reactions between $\left(\mathrm{Fe}^{+}\right)^{*}$ and $\mathrm{CH}_{3} \mathrm{OH}$. Because this reaction is endother- 
mic for $\left(\mathrm{Fe}^{+}\right)^{\circ}$ by $0.70 \pm 0.20 \mathrm{eV}[2 \mathrm{~h}], \mathrm{FeOH}^{+}$must be formed by reactions of $\left(\mathrm{Fe}^{+}\right)^{*}$ ion(s). Because the $\mathrm{FeOH}^{+}$product ion is formed by $\mathrm{C}-\mathrm{O}$ bond insertion of $\left(\mathrm{Fe}^{+}\right)^{*}$, collisional relaxation and formation of $\mathrm{FeOH}^{+}$could possibly involve a common intermediate. There are several $\left(\mathrm{Fe}^{+}\right)^{*}$ states with the correct electron configuration and sufficient energy to form $\mathrm{FeOH}{ }^{+}$. However, collisional relaxation appears to be the dominant reaction channel, and the production of the $\mathrm{FeOH}^{+}$does not significantly affect collisional relaxation data.

The $\mathrm{Fe}_{2}(\mathrm{CO})_{4}^{+}$ionic cluster fragment (reaction 8 ) is formed by reaction of the ground state ${ }^{6} \mathrm{D}\left(\mathrm{Fe}^{+}\right)^{\circ}$ ion, and the rate for formation of $\mathrm{Fe}_{2}(\mathrm{CO})_{4}^{+}$ionic cluster fragments following bimolecular collisional relaxation of $\left(\mathrm{Fe}^{+}\right)^{*}$ provides an estimate for the overall rate at which $\left(\mathrm{Fe}^{+}\right)^{*}$ collisionally relaxes to form the ${ }^{6} D\left(\mathrm{Fe}^{+}\right)^{\circ}$.

\section{Single Exponential Versus Multiexponential $\mathrm{Fe}(\mathrm{CO})_{y}^{+}$Decay Curves}

Single versus multiexponential decay curves are the most commonly used diagnostic to determine whether an ion population is composed of one or more reactive species. However, multiexponential decay curves can be detected only in those cases where the rates of reactions of the two species are significantly different. Previous studies have shown that the reactivity of $\left(\mathrm{Fe}^{+}\right)^{*}$ ions depends upon spin, electron configuration, and/or energy level [2]. Thus, it seems reasonable to assume that collisional relaxation reactions will show similar specificity. Indeed, Figures 1-5 clearly show that the rates of reactions of $\left(\mathrm{Fe}^{+}\right)^{*}$ that yield $\mathrm{Fe}(\mathrm{CO})_{y}^{+}$ charge-transfer product ions are different. With the exception of $\mathrm{Fe}(\mathrm{CO})_{5}^{+}$, which is formed by reaction of only the ${ }^{4} F\left(\mathrm{Fe}^{+}\right)^{*}$ ion, $\mathrm{Fe}(\mathrm{CO})_{y}^{+}(y=1-4)$ ions are formed by reactions of $\mathrm{Fe}^{+}$in more than a single electronic state; thus the measured rate of disappearance of $\mathrm{Fe}(\mathrm{CO})_{y}^{+}$corresponds to the depletion of $\left(\mathrm{Fe}^{+}\right)^{*}$ in several states. In some cases, ions in various states are quenched at significantly different rates and multicomponent decay curves are observed. For example, $\mathrm{Fe}(\mathrm{CO})_{4}^{+}$can be formed by reactions of ${ }^{4} \mathrm{D} \mathrm{Fe}^{+},{ }^{4} \mathrm{P} \mathrm{Fe}^{+}$, and ${ }^{2} \mathrm{G} \mathrm{Fe}^{+}$ions, and the disappearance curves for the $\mathrm{Fe}(\mathrm{CO})_{4}^{+}$(with $\mathrm{He}, \mathrm{Ar}, \mathrm{Kr}, \mathrm{H}_{2},{ }^{2} \mathrm{H}_{2}, \mathrm{~N}_{2}, \mathrm{CO}$, NO, $\mathrm{CH}_{4}$, and $\left.\mathrm{CH}_{3} \mathrm{OH}\right)$ suggest that more than one $\left(\mathrm{Fe}^{+}\right)^{*}$ ion is present. On the other hand, the $\mathrm{Fe}(\mathrm{CO})_{3}^{+}$ charge-transfer product ion can be formed by reactions of the ${ }^{2} P \mathrm{Fe}^{+},{ }^{2} \mathrm{H} \mathrm{Fe}^{+},{ }^{2} D \mathrm{Fe}^{+},{ }^{4} P \mathrm{Fe}^{+}$, and ${ }^{4} \mathrm{H} \mathrm{Fe}^{+}$ ions, but the disappearance curves for $\mathrm{Fe}(\mathrm{CO})_{3}^{+}$(Figures 1-5) do not show distinctive features that can be attributed to different rates. Apparently, collisional relaxation of these states (assuming all states are formed) proceeds at approximately the same rate. The rate of disappearance of $\mathrm{Fe}(\mathrm{CO})_{3}^{+}$following reaction of $\left(\mathrm{Fe}^{+}\right)^{*}$ with $\mathrm{N}_{2}, \mathrm{CO}$, and $\mathrm{CH}_{4}$ shows two distinctive features that correspond to slow and fast relaxation rates. Thus, the reactions with $\mathrm{N}_{2}, \mathrm{CO}$, and $\mathrm{CH}_{4}$ ap- pear to be more sensitive to the different types of $\left(\mathrm{Fe}^{+}\right)^{*}$ than reactions with the other quenching reagents.

$\mathrm{Fe}(\mathrm{CO})_{2}^{+}$is formed by the reaction of $\mathrm{Fe}^{+}$in six electronic states that have two electron configurations $\left(4 s^{2} 3 d^{5}\right.$ and $\left.4 s^{1} 3 d^{6}\right)$ and three spin states (doublet, quartet, and sextet). The disappearance curves for $\mathrm{Fe}(\mathrm{CO})_{2}^{+}$following reactions of $\left(\mathrm{Fe}^{+}\right)^{*}$ with $\mathrm{He}, \mathrm{Ar}$, $\mathrm{Kr}, \mathrm{H}_{2},{ }^{2} \mathrm{H}_{2}, \mathrm{CO}, \mathrm{N}_{2}, \mathrm{NO}, \mathrm{CH}_{4}$, and $\mathrm{CH}_{3} \mathrm{OH}$ clearly show that there are two types of $\left(\mathrm{Fe}^{+}\right)^{*}$ ions in this experiment. A fraction of the $\left(\mathrm{Fe}^{+}\right)^{*}$ ions are depleted by $\mathrm{H}_{2},{ }^{2} \mathrm{H}_{2}, \mathrm{CH}_{4}$, and $\mathrm{CH}_{3} \mathrm{OH}$, but a significant fraction of the ions are unreactive, whereas the disappearance curves for the rare gas atoms are clearly multicomponent. We suggest that the reactive fraction corresponds to $\mathrm{Fe}^{+}$ions in the high lying $s^{1} 3 d^{6} \mathrm{Fe}^{+}$ states and the unreactive fraction corresponds to the ${ }^{6} \mathrm{~S} \mathrm{Fe}^{+}$ions. These assignments are based on molecular orbital considerations and are consistent with the reaction chemistry of $\left(\mathrm{Fe}^{+}\right)^{*}$ with $\mathrm{H}_{2},{ }^{2} \mathrm{H}_{2}, \mathrm{CH}_{4}$, and $\mathrm{CH}_{3} \mathrm{OH}$; that is, the $s^{2} d^{5}$ is a very stable electron configuration and the doubly occupied $s$-orbital is highly repulsive in reactions with ${ }^{2} \mathrm{H}_{2}, \mathrm{CH}_{4}$, and $\mathrm{CH}_{3} \mathrm{OH}$ [32]. Although the decay curve for $\mathrm{Fe}(\mathrm{CO})_{2}^{+}$ following reactions of $\left(\mathrm{Fe}^{+}\right)^{*}$ with $\mathrm{NO}$ appears to show only a single unreactive component, the existence of two types of $\left(\mathrm{Fe}^{+}\right)^{*}$ ions was previously demonstrated [2a]. In addition, collisional relaxation data for $\mathrm{He}, \mathrm{Ar}$, $\mathrm{Kr}, \mathrm{H}_{2},{ }^{2} \mathrm{H}_{2}, \mathrm{CO}, \mathrm{N}_{2}, \mathrm{NO}, \mathrm{CH}_{4}$, and $\mathrm{CH}_{3} \mathrm{OH}$ clearly indicate two different types of $\left(\mathrm{Fe}^{+}\right)^{*}$ ions. Again, the two types of $\left(\mathrm{Fe}^{+}\right)^{*}$ ions probably have the $4 s^{2} 3 d^{5}$ and $4 s^{1} 3 d^{6}$ electron configurations. This point is discussed further in a later section.

The biexponential features in the $\mathrm{Fe}(\mathrm{CO})^{+}$decay curves indicate that $\mathrm{Fe}^{+}$in the state(s) that give rise to $\mathrm{Fe}(\mathrm{CO})^{+}$react via distinctively different relaxation rates, and it is likely that these states are the ${ }^{2} \mathrm{G} \mathrm{Fe}^{+}$ and the ${ }^{2} \mathrm{~F} \mathrm{Fe}^{+}$ions. On the basis of the chargetransfer ion-molecule reaction chemistry data, the ${ }^{2} G$ $\mathrm{Fe}^{+}$is the lowest energy electronic state with sufficient energy to form $\mathrm{Fe}(\mathrm{CO})_{5}^{+}$. It is feasible that other high lying states are present, but the relative abundance of ions in this state(s) is expected to be very small [e.g., less than $3 \%$ of the total $\mathrm{Fe}^{+}$ion population produced by $50-70-\mathrm{eV}$ EI of $\mathrm{Fe}(\mathrm{CO})_{5}$ ].

\section{Comparison of the Relative Relaxation Efficiency of $\left(\mathrm{Fe}^{+}\right) *$ by Different Reagents}

In general, collisional relaxation of $\left(\mathrm{Fe}^{+}\right)^{*}$ with $\mathrm{NO}$ and $\mathrm{CH}_{3} \mathrm{OH}$ is relatively efficient and proceeds with rate constants close to the collision rate. The largest rate constant $\left(2 \times 10^{-9} \mathrm{~cm}^{3}\right.$ molecule $\left.{ }^{-1} \mathrm{~s}^{-1}\right)$ corresponds to the collisional relaxation of $4 s^{1} 3 d^{6}\left(\mathrm{Fe}^{+}\right)^{*}$ states (with energies greater than $10.71 \mathrm{eV}$ ) by $\mathrm{CH}_{3} \mathrm{OH}$. Compared to the rate of relaxation of the other $\left(\mathrm{Fe}^{+}\right)^{*}$ ions, the ${ }^{4} \mathrm{~F} \mathrm{Fe}^{+*}$ ion is the least efficiently quenched ion. NO is the most efficient gas $\left(k \sim 6 \times 10^{-10} \mathrm{~cm}^{3}\right.$ 
molecule ${ }^{-1} \mathrm{~s}^{-1}$ ) for the relaxation of the ${ }^{4} \mathrm{FFe}^{+*}$ ion, and the rare gas atoms are the least efficient (rate constants of $\sim 3 \times 10^{-12}, 3 \times 10^{-12}$, and $2 \times 10^{-12}$ $\mathrm{cm}^{3}$ molecule ${ }^{-1} \mathrm{~s}^{-1}$ for $\mathrm{He}, \mathrm{Ar}$, and $\mathrm{Kr}$, respectively). Also the largest rate constant $\left(k \sim 9 \times 10^{-10} \mathrm{~cm}^{3}\right.$ molecule $e^{-1} \mathrm{~s}^{-1}$ ) for the overall collisional relaxation of $\left(\mathrm{Fe}^{+}\right)^{*}$ to form ${ }^{6} D \mathrm{Fe}^{+}$is for relaxation of $\left(\mathrm{Fe}^{+}\right)^{*}$ by $\mathrm{NO}$, and the smallest rate constant $\left(k \sim 3 \times 10^{-11} \mathrm{~cm}^{3}\right.$ molecule $\left.e^{-1} s^{-1}\right)$ is for collisional relaxation by $\mathrm{He}$.

The $\mathrm{N}_{2}$ and $\mathrm{CO}$ gases collisionally relax $\mathrm{Fe}^{+}$in the ${ }^{4} \mathrm{~F} \mathrm{Fe}^{+}$state less efficiently than ions in the higher energy states, and $\mathrm{CO}$ is a better quenching reagent than $\mathrm{N}_{2}$. In particular, $\mathrm{CO}$ relaxes the $\left(\mathrm{Fe}^{+}\right)^{*}$ ions with energies between 8.90 and $10.51 \mathrm{eV}$ approximately two times faster than $N_{2}$. The largest rate constants $(\sim 6 \times$ $10^{-10}$ and $6 \times 10^{-10} \mathrm{~cm}^{3} \mathrm{~s}^{-1}$ for $\mathrm{N}_{2}$ and $\mathrm{CO}$, respectively) correspond to the collisional relaxation of $\mathrm{Fe}^{+}$ in the $4 s^{1} 3 d^{6}$ states with energies greater than 10.68 $\mathrm{eV}$. Note also that the ${ }^{4} \mathrm{~F} \mathrm{Fe}^{+}$ion is not collisionally relaxed by $\mathrm{CO}$ or $\mathrm{N}_{2}$.

The rate constants for collisional relaxation of $\left(\mathrm{Fe}^{+}\right)^{*}$ by $\mathrm{H}_{2}$ and ${ }^{2} \mathrm{H}_{2}$ are the same to within the experimental error. For example, the overall rate constants for collisional relaxation of $\left(\mathrm{Fe}^{+}\right)^{*}$ by $\mathrm{H}_{2}$ and ${ }^{2} \mathrm{H}_{2}$ are approximately $1 \times 10^{-10} \mathrm{~cm}^{3}$ molecule $\mathrm{c}^{-1} \mathrm{~s}^{-1}$. Note that $\mathrm{H}_{2}$ and ${ }^{2} \mathrm{H}_{2}$ are the only collision gases that more efficiently quench $\mathrm{Fe}^{+}$in high lying states (ionization energies of $11.64 \mathrm{eV}$ and above) than in the low energy states (Table 2).

Compared to the other reagents, rare gas atoms collisionally relax $\left(\mathrm{Fe}^{+}\right)^{*}$ in a relatively inefficient manner. Helium and argon relax ${ }^{4} \mathrm{~F} \mathrm{Fe}^{+}$at approximately the same rate and at a rate that is two times greater than that for $\mathrm{Kr}$. The general trend for the collisional relaxation of the high lying states is in the reverse order. For example, $\mathrm{Kr}$ relaxes $\mathrm{Fe}^{+}$in electronic states with energies greater than $10.68 \mathrm{eV}$ approximately seven times faster than does $\mathrm{He}$ and two times faster than does $\mathrm{Ar}$. The relative rates $(\mathrm{Kr}>\mathrm{Ar}$ $>\mathrm{He}$ ) suggest that collisional relaxation of $\left(\mathrm{Fe}^{+}\right)^{*}$ by rare gas atoms is not a simple physical process [e.g., conversion of electronic energy of $\left(\mathrm{Fe}^{+}\right)^{*}$ to the translational energy of the rare gas atoms (this point is discussed further in a latter section)]. Because the higher lying $\left(\mathrm{Fe}^{+}\right)^{*}$ states have mainly the $4 s^{1} 3 d^{6}$ electron configuration and the first excited state has a $3 d^{7}$ electron configuration, it appears that $\mathrm{Ar}$ and $\mathrm{Kr}$ can interact with the $4 s^{1} 3 d^{6}$ configuration on a more attractive potential surface than that for He.

\section{Mechanism(s) of Collisional Relaxation}

Armentrout [2c, 7] proposed a mechanism for collisional relaxation of excited state metal ions that involves the formation of short-lived collisional intermediates, such as $\left(\mathrm{Fe}^{+}\right)^{*} \cdots \mathrm{Rg}$, when $\mathrm{Rg}$ denotes a rare gas atom. In the specific case of $\left(\mathrm{Fe}^{+}\right)^{*}$, Armentrout reported that relaxation of ${ }^{4} \mathrm{~F} \mathrm{Fe}^{+}$to ${ }^{6} \mathrm{D} \mathrm{Fe}^{+}$requires approximately 600 collisions with $\mathrm{Ar}$, whereas relax- ation of highly excited states of $\left(\mathrm{Fe}^{+}\right)$requires $10^{3}$. collisions with $\mathrm{Ar}$ and $10^{5}$ collisions with $\mathrm{He}$. The inefficiencies of the collisional relaxation processes are rationalized in terms of the low probabilities of interactions between surfaces that evolve from electronic states that have different spins [2c].

Although collisional relaxation efficiencies measured in the ICR experiment appear to contradict Armentrout's data, this clearly is not the case. For instance, collisional relaxation of $\left(\mathrm{Fe}^{+}\right)^{*}$ that gives rise to $\mathrm{Fe}(\mathrm{CO})_{3}^{+}$by $\mathrm{Ar}$ is complete by approximately $1.8 \mathrm{~s}$ (6-10 collisions). However, the abundance of $\left(\mathrm{Fe}^{+}\right)^{*}$ ions that yield $\mathrm{Fe}(\mathrm{CO})^{+}, \mathrm{Fe}(\mathrm{CO})_{2}^{+}, \mathrm{Fe}(\mathrm{CO})_{4}^{+}$, and $\mathrm{Fe}(\mathrm{CO})_{5}^{+}$are still present after 2 -s reaction time. We did not measure the disappearance rate for reaction times greater than $2 \mathrm{~s}$, because other ion loss mechanisms cause ion signal decay. However, at reaction times of $100-500 \mathrm{~s}$ (>500 collisions) measurable amounts of $\left(\mathrm{Fe}^{+}\right)^{*}$ ions are still present.

The most plausible mechanism for collisional relaxation of $\left(\mathrm{Fe}^{+}\right)^{*}$ by the rare gas atoms is the curvecrossing mechanism proposed by Armentrout [2c, 7]. According to a curve-crossing mechanism, collisional relaxation of $\left(\mathrm{Fe}^{+}\right)^{*}$ is likely to occur when the potential energy curves between $\left(\mathrm{Fe}^{+}\right)^{*}$ states and lower lying states cross. Thus, high lying states should be less efficiently quenched to the ground state under thermal collision conditions and the larger rare gas atoms should be more efficient quenchers than the lighter rare gas atoms. The experimental data for relaxation of $\left(\mathrm{Fe}^{+}\right)^{*}$ by $\mathrm{He}, \mathrm{Ar}$, and $\mathrm{Kr}$ are in general agreement with a curve-crossing mechanism. The fact that the trend in the relaxation data for ${ }^{4} \mathrm{FFe}^{+}$is in the reverse order, $\mathrm{He}>\mathrm{Ar}>\mathrm{Kr}$, is probably related to the small energy differences between these states and the promotion energy required for the $3 d^{7}$ to $4 s^{1} 3 d^{6}$ reaction.

In a previous paper [2a], we proposed an electrontransfer mechanism for collisional relaxation of specific states by NO. This mechanism (Scheme I) is only operative for the $4 s^{1} 3 d^{6}\left(\mathrm{Fe}^{+}\right)^{*}$ states with energies greater than $10.68 \mathrm{eV}$, and the product of this reaction is the ${ }^{6} \mathrm{~S} \mathrm{Fe}^{+}$state that has a $4 s^{2} 3 d^{5}$ electron configuration. We proposed that the reaction $4 s^{1} 3 d^{6} \rightarrow 4 s^{2} 3 d^{5}$ occurs by $\pi^{*}$ electron transfer from NO to the $s$-orbital of $\left(\mathrm{Fe}^{+}\right)^{*}$ and back-donation of the $\mathrm{Fe}^{+} d$-orbital electron to the empty NO $\pi^{*}$-orbital. Such a reaction is only possible if the total energy of the $\left(\mathrm{Fe}^{+}\right)^{*}$ state [ionization energy of the $\mathrm{Fe}^{+}$plus the energy of the $\left.\left(\mathrm{Fe}^{+}\right)^{*}\right]$ is greater than the ionization energy of NO $(9.26 \mathrm{eV})$ [2a]. Apparently, this reaction is in direct competition with the charge-transfer reaction channel.

The $\mathrm{H}_{2}$ and ${ }^{2} \mathrm{H}_{2}$ collisional relaxation data sharply contrast with the NO results. In particular, the high lying $(10.68-\mathrm{eV}) 4 s^{1} 3 d^{6}\left(\mathrm{Fe}^{+}\right)^{*}$ states do not react with $\mathrm{H}_{2}$ and ${ }^{2} \mathrm{H}_{2}$ to form the ${ }^{6} \mathrm{~S} \mathrm{Fe}^{+}$ion. Note the decrease in the abundance of $\mathrm{Fe}(\mathrm{CO})_{2}^{+}$ions with $\mathrm{H}_{2}$ collision gas during the first $400 \mathrm{~ms}$, but the relative abundance of these ions remains constant between $400 \mathrm{~ms}$ and $2 \mathrm{~s}$. 
$\mathrm{Fe}^{+}\left(4 \mathrm{~s}^{1} 3 \mathrm{~d}^{6}\right)+\mathrm{NO}$<smiles>C[Te]</smiles>

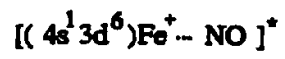<smiles>[CH]C</smiles>

$\left[\left(43^{2} 3 d^{6}\right) \mathrm{Fe}-\mathrm{NO}^{+}\right]^{*}$

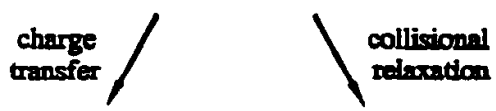

$\left(4 s^{2} 3 d^{6}\right) \mathrm{Fe}+\mathrm{NO}^{+} \quad\left(4 s^{2} 3 d^{5}\right) \mathrm{Fe}^{+}+\mathrm{NO}$

Scheme 1

Thus, a substantial fraction of the $\left(\mathrm{Fe}^{+}\right)^{*}$ ions, probably the ${ }^{6} \mathrm{~S} \mathrm{Fe}^{+}$, does not react with $\mathrm{H}_{2}$. Because the single $\pi^{*}$ electron of NO plays a critical role in the formation of the ${ }^{6} \mathrm{~S} \mathrm{Fe}^{+}$ion via an electron-transfer reaction, such a process is not accessible in reactions of $\left(\mathrm{Fe}^{+}\right)^{*}$ with $\mathrm{H}_{2}$ or ${ }^{2} \mathrm{H}_{2}$. That is, collisional relaxation of high lying $s^{1} d^{6}\left(\mathrm{Fe}^{+}\right)^{*}$ states by $\mathrm{H}_{2}$ and ${ }^{2} \mathrm{H}_{2}$ must proceed directly to the $\left(\mathrm{Fe}^{+}\right)^{\circ}$ and $/$ or $\left(\mathrm{Fe}^{+}\right)^{*}$ state(s) that are not coupled to the ${ }^{6} \mathrm{~S} \mathrm{Fe}^{+}$state. It is possible that relaxation of the high lying $s^{1} d^{6} \mathrm{Fe}^{+}$ions occurs by a mechanism that involves $\mathrm{H}-\mathrm{H}$ bond insertion followed by reductive elimination of rovibrationally excited $\mathrm{H}_{2}$ or ${ }^{2} \mathrm{H}_{2}$ (see subsequent text).

Ridge and co-workers [2h, 2i] invoked a chemical relaxation reaction to explain results for the $\mathrm{Cr}^{+} / \mathrm{CH}_{4}$ system. It is possible that a similar mechanism also is operative for $\left(\mathrm{Fe}^{+}\right)^{*}$ reaction with $\mathrm{H}_{2},{ }^{2} \mathrm{H}_{2}, \mathrm{CH}_{4}$, and $\mathrm{CH}_{3} \mathrm{OH}$. That is, $\left(\mathrm{Fe}^{+}\right)^{*}$ undergoes oxidative insertion into the $\mathrm{H}-\mathrm{H}, \mathrm{C}-\mathrm{H}$, and $\mathrm{C}-\mathrm{O}$ bonds, energy is partitioned into available degrees of freedom, and the collision complex then dissociates to reactants. The ability of $\left(\mathrm{Fe}^{+}\right)^{*}$ to insert into the $\mathrm{H}-\mathrm{H}, \mathrm{C}-\mathrm{H}$, and $\mathrm{C}-\mathrm{O}$ bonds is strongly dependent upon the electronic configuration of the reacting $\left(\mathrm{Fe}^{+}\right)^{*}$ state $[2 \mathrm{c}, 2 \mathrm{~g}$, 17]. The $3 d^{7}\left(\mathrm{Fe}^{+}\right)^{*}$ ions insert more readily than do $4 s^{1} 3 d^{6}\left(\mathrm{Fe}^{+}\right)^{*}$ ions, and the $4 s^{2} 3 d^{5}\left(\mathrm{Fe}^{+}\right)^{*}$ ions are more repulsive than the other two electronic configurations. On the basis of this argument the $3 d^{7}$ states should be quenched more efficiently by reactions with $\mathrm{H}_{2},{ }^{2} \mathrm{H}_{2}, \mathrm{CH}_{4}$, and $\mathrm{CH}_{3} \mathrm{OH}$ than the $4 s^{1} 3 d^{6}$ states. Indeed the $\left(\mathrm{Fe}^{+}\right)^{*}$ that give rise to $\mathrm{Fe}(\mathrm{CO})_{y}^{+}(y=3$ and 4) are comprised mostly of $3 d^{7}\left(\mathrm{Fe}^{+}\right)^{*}$, and these states are depleted more efficiently than are $\left(\mathrm{Fe}^{+}\right)^{*}$ ions that react to form $\mathrm{Fe}(\mathrm{CO})_{2}^{+}$and $\mathrm{Fe}(\mathrm{CO})^{+}$ions.

The chemical relaxation mechanism also is supported by the observation that $\mathrm{H}_{2},{ }^{2} \mathrm{H}_{2}, \mathrm{CH}_{4}$, and $\mathrm{CH}_{3} \mathrm{OH}$ only quenches a fraction of $\left(\mathrm{Fe}^{+}\right)^{*}$ states that give rise to $\mathrm{Fe}(\mathrm{CO})_{2}^{+}$charge-transfer product ions. The fraction of $\left(\mathrm{Fe}^{+}\right)^{*}$ ions that are quenched by these four reagents corresponds to the $4 s^{1} 3 d^{6}\left(\mathrm{Fe}^{+}\right)^{*}$ ions, and we suggest that the unreactive fraction corresponds to the $4 s^{2} 3 d^{5}\left(\mathrm{Fe}^{+}\right)^{*}$ ions. Bond insertion by $4 s^{2} 3 d^{5} \mathrm{Fe}^{+}$ is unfavorable due to the doubly occupied $4 s$-orbital, which cannot accept $\sigma$-electron(s) from $\mathrm{H}-\mathrm{H}, \mathrm{C}-\mathrm{H}$, or $\mathrm{C}$-O . Furthermore, the $4 s^{2} 3 d^{5}\left(\mathrm{Fe}^{+}\right)^{*}$ ion also does not have spin-paired $d$-electrons to donate in the empty $\sigma^{*}$-orbital of the neutral reactant; thus it is highly unreactive.

\section{Conclusion}

It is demonstrated from the results presented in this paper that bimolecular collisional relaxation dynamics of $\left(\mathrm{Fe}^{+}\right)^{*}$ can be probed by using dissociative and nondissociative ion-molecule reaction chemistry under low pressure FT-ICR experimental conditions. On the basis of these results we conclude that $\left(\mathrm{Fe}^{+}\right)^{*}$ ions undergo collisional relaxation reactions to form $\left(\mathrm{Fe}^{+}\right)^{\circ}$ ions or lower energy $\left(\mathrm{Fe}^{+}\right)^{*}$ ions. The relaxation dynamics are complex and vary dependent on the nature of the collisional relaxation reagent and/or the energy level and electron configuration of the $\left(\mathrm{Fe}^{+}\right)^{*}$. For instance, NO collisionally relaxes $4 s^{1} 3 d^{6}\left(\mathrm{Fe}^{+}\right)^{*}$ with ionization energies greater than $10.68 \mathrm{eV}$ by an electron-transfer mechanism, whereas $\mathrm{H}_{2},{ }^{2} \mathrm{H}_{2}, \mathrm{CH}_{4}$, and $\mathrm{CH}_{3} \mathrm{OH}$ relax the $\left(\mathrm{Fe}^{+}\right)^{*}$ ions by a chemical relaxation mechanism. $\mathrm{NO}, \mathrm{CH}_{4}$, and $\mathrm{CH}_{3} \mathrm{OH}$ are the most efficient quenching reagents, with rate constants that approach the Langevin collision rate. The rare gas atoms are the least efficient quenching reagents.

\section{Acknowledgment}

This research was supported by the U.S. Department of Energy, Division of Chemical Sciences, Office of Basic Energy Sciences (DE-A505-82ER13023), and the Robert A. Welch Foundation. The authors wish to thank Petra van Koppen, Peter B. Armentrout, Michael T. Bowers, Fred H. Strobel, Kermit K. Murray, and Gary $R$. Kinsel for many useful discussions and comments, and Julie Wilson for her editing skills.

\section{References}

1. (a) Russell, D. H., Ed. Gas Phase Inorganic Chemistry; Plenum: New York, 1989; pp 1-42; (b) Eller, K.; Schwarz, H. Chem. Rev. 1991, 91, 1121-1177.

2. (a) Oriedo, J. V. B.; Russell, D. H. J. Am. Chem. Soc. 1993, 115, 8376-8381; (b) Armentrout, P. B. Science 1991, 251, 175-179; (c) Armentrout, P. B. Ann. Rev. Phys. Chem. 1990, 41, 313-344; (d) Elkind, J. L.; Armentrout, P. B. J. Phys. Chem. 1987, 91, 2037-2045; (e) Hanton, S. D.; Noll, R. J.; Weisshaar, J. C. J. Phys. Chem. 1990, 94, 5655; (f) van Koppen, P. A. M.; Kemper, P. R.; Bowers, M. T. I. Am. Chem. Soc. 1992, 114, 1083-1084; (g) van Koppen, P. A. M.; Kemper, P. R.; Bowers, M. T. J. Am. Chem. Soc. 1992, 114, 10941-10950; (h) Reents, W. D., Jr.; Strobel, F. H.; Freas, R. B.; Wronka, J.; Ridge, D. P. J. Phys. Chem. 1985, 89, 5666-5670; (i) Strobel, F. H.; Ridge, D. P. I. Phys. Chem. 1989, 93, 3635-3639.

3. Peake, D. A.; Gross, M. L. Anal. Chem. 1985, 57, 115.

4. MacMillian, D. K.; Gross, M. L. In Gas Phase Ion Chemistry; Russell, D. H., Ed.; Plenum: New York, 1989; pp 369-401. 
5. (a) Buckner, S. W.; Freiser, B. S. In Gas Phase Ion Chemistry; Russell, D. H., Ed.; Plenum: New York, 1989; pp 279-322; (b) Dunbar, R. C. In Gas Phase Ion Chemistry; Russell, D. H., Ed.; Plenum: New York, 1989; pp 323-352.

6. (a) Forbes, R. A.; Lech, L. M.; Freiser, B. S. Int. I. Mass Spectrom. Ion Processes 1987, 77, 107-121; (b) Cassady, C. J.; Freiser, B. S. J. Am. Chem. Soc. 1985, 107, 1566-1573.

7. Loh, S. K.; Fisher, R. E.; Lian, L.; Schultz, R. H.; Armentrout, P. B. J. Phys. Chem. 1989, 93, 3159-3167.

8. Oriedo, I. V. B.; Russell, D. H. J. Phys. Chem. 1992, 96, 5314-5319.

9. Kerley, E. L.; Russell, D. H. Anal. Chem. 1989, 61, 53-57.

10. Ghaderi, S.; Littlejohn, D. Proceedings of the 33rd Annual Conference on Mass Spectrometry and Allied Topics; San Diego, CA, 1985; p 727.

11. Rosenstock, H. M.; Draxl, K.; Steiner, B. W.; Herron, J. T. J. Phys. Chem. Ref. Data 1977, 6, I-485.

12. Kerley, E. L.; Russell, D. H. J. Am. Chem. Soc. 1990, 112, 5959-5965.

13. Hanson, C. D.; Kerley, E. L.; Russell, D. H. In Treatise on Analytical Chemistry, Part I; Winefordner, J. D., Ed. 1989; Vol. 2, pp 117-187.

14. Beauchamp, J. L.; Armstrong, J. T. Rev. Sci. Instrum. 1969, 40, 123-128.

15. Hanson, C. D.; Castro, M. E.; Russell, D. H. Anal. Chem. 1989, 61, 2130-2136.

16. Winters, E. R.; Collins, J. H. J. Phys. Chem. 1966, 70, 2057-2058.

17. Noggle, J. H. Physical Chemistry on a Microcomputer; Little, Brown: Boston, 1985; p 1.

18. Kerley, E. L.; Russell, D. H. J. Am. Chem. Soc. 1990, 112, $5959-5965$.
19. Bartmess, J. E.; Georgiadis, R. M. Vacuum 1983, 33, 149-153. 20. (a) Foster, M. A.; Beauchamp, J. J. Am. Chem. Soc. 1975, 97, 4808; (b) Fredeen, D. A.; Russell, D. H. J. Am. Chem. Soc. 1985, 107, 3762.

21. Garstang, R. H. Mon. Not. R. Astron. Soc. 1962, 124, 321-341.

22. (a) Distefano, G. J. J. Res. Bus. Stand. A Phys. Chem. 1970, 74, 233-238; (b) Rosenstock, H. M.; Draxl, K.; Steiner, B. W.; Herron, J. T. J. Chem. Phys. Ref. Data 1977, 6, I-157.

23. Norwood, K.; Ali, K.; Flesch, G. D.; Ng, C. Y. J. Am. Chem. Soc. 1990, 112, 7502-7508.

24. Russell, D. H.; Oriedo, J. V. B.; Solouki, T. In Gas Phase Organometallic Chemistry; Freiser, B. S., Ed.; Kluwer: Amsterdam, in press.

25. Oreido, V. B. J.; Solouki, T.; Russell, D. H. Preliminary results presented at the 41st ASMS Conference on Mass Spectrometry, San Francisco, CA, May 31-June 4, 1993; pp 302a-203b.

26. Tecklenberg, R. E.; Brickner, D. L.; Russell, D. H. Organometallics 1988, 7, 2506-2514.

27. Rosenstock, H. M.; Draxl, K.; Steiner, B. W.; Herron, J. T. J. Phys. Chem. Ref. Data 1977, 6, I-71.

28. Rosenstock, H. M.; Draxl, K.; Steiner, B. W.; Herron, J. T. J. Phys. Chem. Ref. Data 1977, 6, I-582.

29. Rosenstock, H. M.; Draxl, K.; Steiner, B. W.; Herron, J. T. J. Phys. Chem. Ref. Data, 1977, 6, I-267.

30. Lias, S. G.; Bartmess, J. E.; Liebman, J. F.; Holmes, J. L.; Levin, L. D.; Mallard, W. G. J. Phys. Chem. Ref. Data, Suppl. 1, 1988, 17,631 .

31. Schultz, R. H.; Elkind, J. L.; Armentrout, P. B. J. Am. Chem. Soc. 1988, 110, 411-423.

32. Armentrout, P. B. In Gas Phase Inorganic Chemistry: D. H. Russell, Ed.; Plenum: New York, 1989. 